\title{
Soap is the onset of civilization
}

Kees van Dijk

'We are dirty, We are dirty. We do not know how to wash ourselves. We have not acquired education.' These were just some of the lines children in colonial Rhodesia had to sing early in the twentieth century on their first day at school at the St Faith Mission while they were being marched to a stream (Burke 1996:196). Were those children dirty? Besides washing, they may have smeared their bodies with a mixture of soil and oil or fat to repel the dirt, but I am sure they were not dirty. Smearing oneself with soil and oil may sound strange but in sixteenth-century England dirt was removed from clothes by smearing them 'with mud or scouring them with dung' (Cunnington and Cunnington 1992:47). Why then did the St Faith missionaries force these children to sing that they did not know how to wash themselves? The answer probably is that they did not use soap.

In the course of the nineteenth century soap was appropriated in certain European and American circles, of which Christian revivalists were in the vanguard, to emphasize cultural superiority. Soap was presented as the talisman to modernization. A Unilever slogan even exults that 'Soap is civilization' (McClintock 1995:207) (Figure 1.) In a 1890 advertisement for one particular brand, Pears' Soap, the washing ashore of a soapbox somewhere along the coast of Equatorial Africa was hailed as 'The birth of civilization'. The consumption of soap was 'a Measure of the Wealth, Civilisation, Health and Purity of the People' (Richards 1990:140-1). The person portrayed in the advertisement does not look like an inhabitant of Africa; he looks much more like a fantasy of a South Sea Islander. This gives the message conveyed an additionally nasty flavour. From the 1840s coconut oil extracted from copra had been in great demand as an ingredient of soap. As copra became a much sought-after commodity - 'the glory and the wealth of the South Sea islands' (Forbes 1875:52) - it led to an influx of ruthless Western businessmen and adventurers. The aftermath on Hawai' $i$, Samoa and other Pacific islands was civil war, alienation of land, 
THE BIRTH OF CIVILIZATION - A MESSAgE FROM THE SEA ::

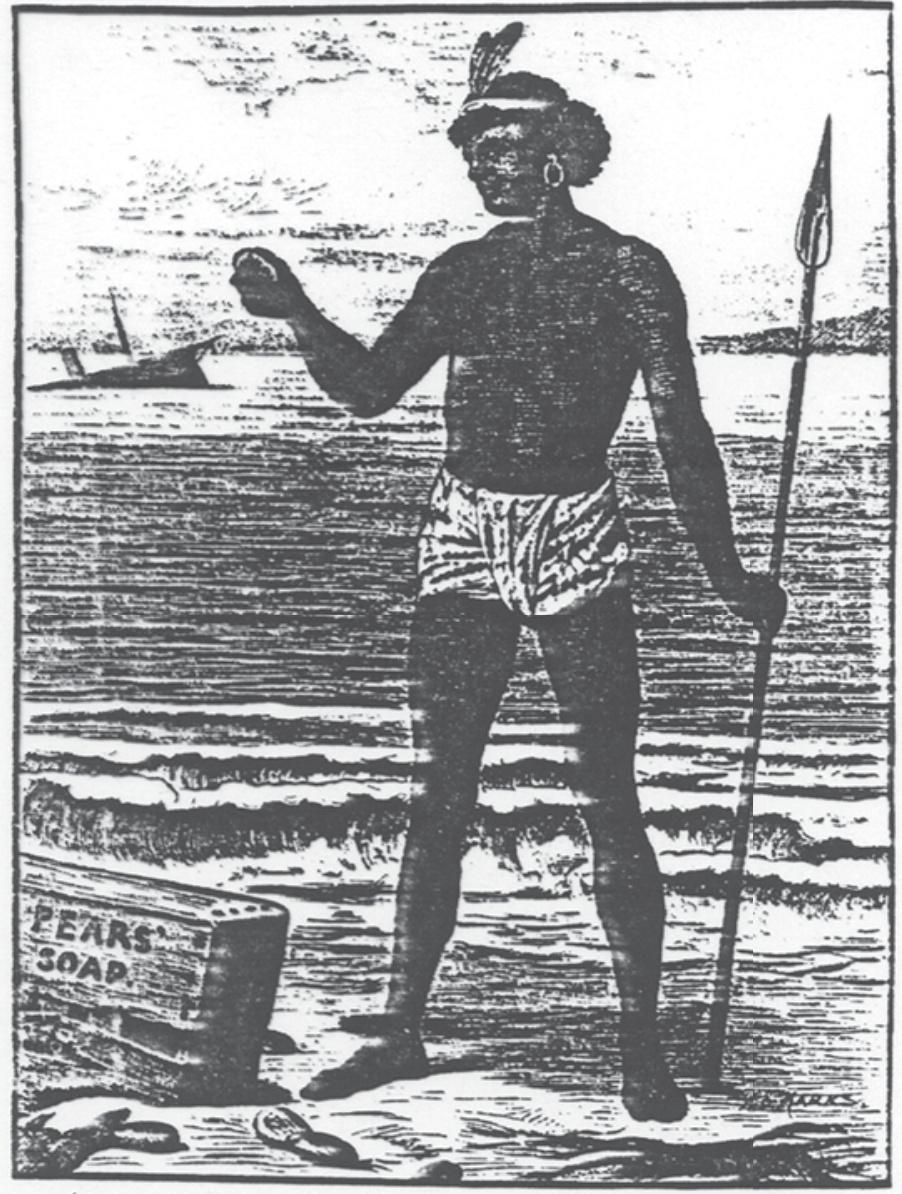

The Consumption ce Scar a a veasure of the wealth, Civilisation.

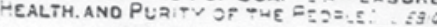

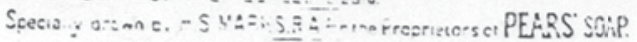

Figure 1. 'The birth of civilization'. A Pears' Soap advertisement. 
forced labour recruitment and migration, and the destruction of the local social structure and culture. ${ }^{1}$

Soap was not the only reference point on the scale of civilization. There were many: dress, language, and even the toilet. The man who was most adamant about the glorious function of our loo was George Jennings, the successful designer of a wash-down closet. He proudly displayed his patented flushed water-closet at the 1851 Great Exhibition in London, the supreme opportunity to show off the accomplishments of Western technology, and the first in a long series of World Exhibitions. His contraption was a great success. It conquered the world and at the Great Exhibition over 827,280 visitors paid a penny to use Jennings' 'monkey-closet'. ' Jennings once observed that 'the civilization of a people can be measured by their domestic and sanitary appliances,' although he may have had monetary considerations and the domestic or Western market rather than a civilizing mission in the forefront of his mind (Horan 1996:85, 88 ). It is too good an opportunity to fail to point out that Jennings' yardstick would have placed the European colonial community in British India rather low on the scale of civilization. In 1856 there still were no water-closets in Government House in Calcutta, the official residence of the Governor-General (Dalrymple 2006:122).

Water closets had been known since the end of the sixteenth century, but had not enjoyed great success. There was always the risk they could cause cesspits to overflow and consequently needed an expensive sewage system. Other drawbacks were that they could leak and, most importantly, that the waste-pipe went straight down. The goose neck had not yet been invented to isolate the smell of the sewer from the house. Rather than being hailed as a blessing, water closets were even considered decadent and wasteful. Nevertheless, it was an invention greatly esteemed by the English. It was a marker of their advanced level of civilization. Water closets created a way of relieving oneself far superior to the way the Dutch, or for that matter any other nationality abroad. It made the Dutch, among other nations, look very backward. Dutchmen in need sought the waters of a lake, as the drawing of James Gilray from 1796 'Dutch convenience - the lake' shows (Cockayne 2007:144; Horan 1996:72-5). Later, for instance in Siam during the reign of King Rama V (r. 1868-1910), one of those modernizing monarchs at the turn of

1 About a decade later copra would become an important ingredient for the manufacture of candles. Because of the American Civil War the South Pacific also became an important producer of cotton, giving an additional impetus to the exploitation of the Islanders.

2 Seealso:http://home.netlinc.org.uk/ContentStore/_Public/Documents/0019400/19478/ cdrom/East\%20Midlands/victorian/timeline.htm (accessed 10-6-2011). 
the last century, toilets did indeed become one of the symbols of the drive towards civilization. Shitting around had become a sign of backwardness. Not everybody agreed. There were advantages in selecting a nice place in a field with a good view and a cool breeze as a Thai farmer told an American doctor somewhat later: 'You Americans are strange. Before you came here, if I felt like relieving myself, I found a quiet spot in the open with gentle breezes and often a pleasant vista. Then you came along and convinced me that this material that comes from me is one of the most dangerous things with which people can have contact. In other words I should stay away from it as far as possible. Then the next thing you told me was that I should dig a hole, and not only I, but many other people should concentrate this dangerous material in that hole. So now I have even closer contact not only with my own but everyone else's, and in a dark, smelly place with no view at that.' (Hanlon 1969:67.)

The flush toilets developed by Jennings and others turned out to be a dubious contribution to civilization, not to speak of cleanliness. Though for many who used the Jennings' water closet at the Great Exhibitions this was a novel experience, the middle of the nineteenth century was the moment at which WCs were being installed in increasingly more houses in London and in other European cities. In London water now entered the city's drainage system in abundance, and enriched with what it had flushed away ended up in the River Thames. The amount of faecal matter daily dispensed in this way was enormous: in the 1840s some 250 tons, in the 1860 thousands of tons (Smith 2007:279). In 1858, seven years after the Great Exhibition, during an exceptionally hot summer London endured its Great Stink. ${ }^{3}$

The water closet conquered only part of the world. In 1943, when Ibn Saud, King of Saudi Arabia, met President Roosevelt aboard the USS Quincy, the way in which his sixty-men entourage answered nature's call by simply leaning over the rail upset American sailors, as they probably had to clean the mess on the deck (Oren 2007:472). And even nowadays modern tourists in Paris may go to McDonalds not to eat but in search of a decent toilet and not a simple hole in the ground (Lagarde 2005).

Nevertheless, it was soap which emerged as the pre-eminent marker of personal hygiene and civilization in European eyes. Soap ensured people were physically clean and helped them meet one of the criteria of being civilized.

3 Halliday 1999:42-7. Because of this problem, some British cities discouraged the use of water closets (Halliday 1999:45). For similar problems in France, see Barnes 2006. 
At this point it must be remembered that bodily hygiene had disappeared from Europe after the Middle Ages. In the Renaissance people had still found pleasure in taking a bath (Roche 2000:158-9). They had also detested body odours, preferring to smell sweet (Smith 2007:158). Italians especially had 'cared deeply about being clean and keeping their environment clean' (Biow 2006:xii). In Northern Europe it may have been thought that the way they did so was a little excessive. In one story recounted around 900 by the Swiss monk Notker of St Gall (840-912), also known as Notker the Stammerer, entitled The deacon who washed too much readers are warned not to embrace the grooming 'habits of the Italians'. The over-hygienic deacon 'used to take baths, he had his head very closely shaved, he polished his skin, he cleaned his nails, he had his hair cut sort as if it had been turned on a lathe, and he wore linen underclothes and a snow-white shirt' (Smith 2007:148).

Washing was part of this Italian lifestyle, but the sensation of being clean was above all evoked by putting on fresh, pleasantsmelling clothes. Washing with water was not especially essential. Wiping off dirt or rubbing one's body clean and changing clothes could suffice, both then and later in European history. Consequently, in those days soap was more important as a means to clean clothes than it was to clean bodies (Biow 2006:15, 99; Cockayne 2007:60; Ashenburg 2008:106-7). Such emphasis on changing clothes indicates that the persons whose bodily hygiene is described here must have had money. It goes without saying that region, social class and wealth all can cause differences in the use of water and also of soap. Soap was available, but even when it was not excessively greasy and did not act as an irritant to the skin when cleaning the body, it was too expensive to be affordable to many (Cockayne 2007:60).

Whatever the case and with the exception of such countries with a strong sauna tradition as Finland, Russia, and Ireland (Aaland 1978:72, 115, 122-5, 132-3), there was, what one author described, a 'flight of the elites from the bath' after the Renaissance (Roche 2000:159). To bathe it was usually necessary to undress (though as we can observe nowadays among some strict Muslim women using swimming pools or going to the beach, not necessarily so) and the growing influence of Christianity and its rejection of nudity certainly had something to do with this. A variety of saints, male and female, had for centuries decided that a sound and devout mind should be housed in a filthy body and had stopped washing them- 
selves and their clothes. ${ }^{4}$ Still, exceptions were made. In his Règles de la bienséance et de la civilité chrétienne from 1695, the seventeenthcentury French Saint Jean-Baptiste de la Salle (1651-1719) urged people to wash their ears in order to hear better what was said in church (Perrot 1987).

For a long time such a saint may have belonged to 'a vociferous minority of religious puritans' (Smith 2007:140) and did indeed at first form an exception but in the end their repulsion to cleanliness prevailed. In the sixteenth and seventeenth centuries, the popular medieval communal bathhouses, a continuation of Greek, Roman and local traditions, were considered all the more offensive as in some people of both sexes mingled. They began to be looked on as dens of iniquity and disappeared from the cities and villages. Steam baths which Crusaders had discovered in the Middle East suffered a similar fate (Perrot 1987:13). The Church condemned such worldly pleasures as taking a bath and enjoying it. Even anti-Islamic sentiments played a role. In Spain the situation did not improve when Christianity prevailed over the Peninsula. Ashenburg (2008:111) argues that because 'the Moor was clean, the Spanish decided that Christians should be dirty'. Bathing was considered to be a Muslim, Moorish custom. Bath houses were banned in 1576 and the Inquisition considered taking a bath an indication that converted Muslims and Jews were reverting to their old ways. Temporal authorities also may have found the sight of the lower classes bathing in rivers morally offensive. Church and Government fought a losing battle. The habit of swimming in rivers was very difficult to eradicate, also as it was a popular pastime even among the elite. ${ }^{5}$

At least in France, but probably all over Europe, smelling foul became associated with strength, health, and wealth. At least up to the end of the eighteenth century, some medical doctors believed

4 Smith 2007:134-9; Ashenburg 2008:58-62. The unwashed saint emerged early in Christianity. The most famous perhaps is Saint Francis of Assisi (1181-1226), who, as it is observed with some astonishment on a website devoted to him (Bonacorsi n.d.), 'went on behaving more and more strangely, up to when he start walking around Assisi dressed in rags and very dirty'. To Francis of Assisi a dirty body was 'a stinking badge of piety' (Ashenburg 2008:60). The examples Virginia Smith (2007:138-9) mentions include St Melania (383-439) and St Anthony (1195-1231). A more recent example is Benedictus Labre (1748-1783) who ate the vermin which covered him and believed in the virtues of excreta (Corbin 1986:274), a fact which now tends to be glossed over in any mentions of this saint. Equally old is the lashing out at bath-houses. St Jerome (340420) regarded public baths as 'evil' and St Athanasius (296-373), considering a basin 'sufficient $[\ldots]$ to wash away your dirt', fulminated against 'the women who bathe $[\ldots]$. And have dragged others down into corruption.' (Smith 2007:139.)

5 Roche 2000:163-4; Smith 2007:201, 219. Until the beginning of the nineteenth century, precautions were taken at the Dutch bathing resort of Scheveningen to spare the well-to-do seaside visitors the sight of ordinary villagers bathing naked in the sea (Kuus 2007:16). 
in the medicinal merit of stench to combat the plague, while others thought that a bath in excreta could even cure that pestilence. Labourers engaged in smelly jobs were also convinced of the benefits to their health of noxious odours (Corbin 1986:267-8). Some people even feared that frequent bathing would rob them of their strength. Others, and this was a widely held notion, considered bathing a health hazard (Soo and Stevenson 2007:37; Roche 2000:158, 163; Corbin 1986:59-62). Carl Linnaeus (1707-1778), the famous eighteenth-century botanist whose profession was medical doctor, also did his bit to promote rankness, warning that washing one's hair might cause epilepsy (Koerner 1996:158). And, for the sake of honesty, it has to be admitted that the fear of catching syphilis (a new disease in Europe around 1500) and the plague certainly also played a role in the disappearance of bathhouses (Smith 2007:179-82).

Elsewhere in the world people did not stop bathing Europeans noted. Emily Cockayne (2007:60) observes that such minor routines as cleaning the body are hardly mentioned in diaries, travel reports and other literature. Although this is generally true, the exception is when something unexpected is observed. Maybe this is why frequent bathing and the washing of hair are often mentioned by late-sixteenth- and early-seventeenth-century Europeans visiting Asia. One of them, Jan Huygen van Linschoten, observed in his famous Itinerario that villagers near Goa in India and the indigenous wives of the Portuguese living in that city washed their bodies daily, a habit he dismisses as a useless ritual (Van den Boogaart 2000:20-2; Rouffaer and IJzerman 1925:29, 306-7; Breet 2003:446-7). Such travellers could also observe that taking a bath might even have a social and ceremonial function. When the commander of a small English fleet, Thomas Best, visited Aceh in 1613 he noted in his diary that the 'King invighted me to his founteyne to swime [...]. And having washed and bathed ourselves in the water, the Kinge presented us with an exceedinge greate bankett, with two much rack [arak]; all to be eaten and druncke as wee sett in the water; all his nobles and greate captaynes beinge presente.' (Foster 1934:55.) It is an early reference to the water palaces of the rulers in the region. Called by the Dutch waterkastelen (water castles) or lusthoven (gardens of delight), they were built in such places as Cirebon (Sungaragih) and Yogyakarta (built by Sultan Hamengkubuwono I between 1758 and 1765). ${ }^{6}$ Elsewhere in the East the same fondness for taking a

6 In Yogyakarta there were two such bathing palaces: Taman Sari (Garden of Delight) and Taman Ledok (Lower Garden). How beautiful and imposing the Yogyakarta 'water palace' may once have been can be surmised from its depiction in Thorn (1815, 2004: Plate XXV). See also Dumarçay 1978, Groneman 1885 and Bosboom 1902. 
bath was observed. In retrospect, some authors who acknowledge the 'Hindu love of washing' are even sure that the Indian bathing habits contributed to the spread of new notions of hygiene in Great Britain (Spear 1998:146; Smith 2007:235).

\section{SWEEPING THE STREETS}

Europe and Europeans must have stunk - in some regions more than in others - in the seventeenth, eighteenth, and nineteenth centuries. One small contribution to this was that there were no inhibitions about breaking wind. And when farting was disapproved of, we can conclude from morality books, such as an early sixteenth-century work by Erasmus (1530, and still reprinted in the eighteenth century), which bear a strong resemblance to a collection of fatwas, and an early eighteenth-century treatise by La Salle (1729), it was the noise which was considered offensive not the stench. ${ }^{7}$ Nevertheless not all was dirt. Clothes, furniture, except for beds which were hardly ever aired and stank, floors, and streets were cleaned (Cockayne 2007:58-9). In France and England this did not perhaps occur as fanatically as in the Netherlands. In Schama's description (1988:375-85) in his The embarrassment of riches, Dutch housewives and maids of the seventeenth century so absorbed in scrubbing and polishing emerge as members of a weird Calvinist sect, not fully understood and appreciated by contemporaries abroad.

The overwhelming Dutch passion for cleanliness in cities also made a lasting impression on the Malays. One of the persons who figures in Abdullah bin Abdul Kadir's autobiography Hikayat Abdullah (finished in 1843) is Mr Bamgoor. His real name must have been Van Goor, Secretary to the Dutch Governor of Malacca in 1818. Bamgoor, also known as Mr. Sweep, is portrayed as being obsessed with urban cleanliness. Each night he inspects the streets and hands out fines to inhabitants when rubbish is left lying in front of their houses. Abdullah bin Abdul Kadir calls him 'a leech, drinking the blood of Allah's servants'. Consequently: 'When Bamgoor came out of the Fort riding his horse there was everywhere a general rush for home to get brooms and to start sweeping in front of the houses, until the noise of sweeping rent the air. Because people were afraid of being fined...' But revenge was sweet. God inter-

7 Perrot 1987:15; Elias 2001:90, 196-7, 199. The term morality books I borrow from the field of Chinese Studies and the discussions of shansu (morality books) literature. See, for instance, King (2007) 
vened and 'before three months were out Mr. Sweep became ill and demented, crying out constantly in fear and declaring that people had struck him' (Abdullah bin Abdul Kadir1970:148-9).

Differences between European countries have to be taken into consideration. The Dutch cleaning mania was not unique in its sort. Around 1400 one of its prominent citizens of Florence, Leonardo Bruni, praised the city as being 'so clear and neat that no other city could be cleaner'. In Florence nothing was to be found that was 'disgusting to the eye, offensive to the nose, or filthy under foot' (Kohl 1978:138). Later, in the sixteenth and seventeenth century Swiss and German cities enjoyed a similar reputation to those in the Netherlands (Ashenburg 2008:4, 103), but in the same period it is not difficult to find descriptions of foul-smelling French and English cities, especially in the summer. In the 1650s the Common Council of London concluded that the city's streets were 'extreme offensive to the Inhabitants and Passengers, with ashes, dust, dirt, rubbish and filth, and with noysome and unwholsome smels' (Cockayne 2007:184-5). One century later it was decided that the streets of the city were so filthy that it might have been inhabited by 'a herd of barbarians, or a colony of hottentots' (Cockayne 2007:181). In 1777 a high official of the Russian Ministry of Foreign Affairs, Denis Fonvizin (2006:46, 120) admittedly no friend of the French, wrote home to his sister that he had arrived in France and that there was no doubt about that: the awful stench in the very first French city he had entered. It was the same in all towns and villages in France. It was essential to pinch one's nose. There was nothing for the Russians to borrow from the notion of cleanliness of the French, of their moral behaviour still less.

\section{REDISCOVERING THE CLEAN BODY}

Bathrooms or the pleasure people found in bathing had not completely disappeared, but the idea that washing might actually be healthy only gained ground in the second half of the eighteenth century (Roche 2000:162-5). Concurrently, what Corbin (1986:85) calls a decrease in the tolerance of smells began to evolve among the elite. The passion for smelling sweet and pleasant returned (Corbin 1986:106). It was the period in which the aristocracy and the elites returned to their bathrooms, which eventually became essential elements in their houses (Smith 2007:230, 234-5). Consequently, bodily hygiene became a characteristic of the rich, and well into the twentieth century stinking was presented as a marker of social backwardness and of the lower orders, the working class and the poor, 
who had no option but to live in dismal circumstances (Soo and Stevenson 2007:36-7; Perrot 1987:108; Corbin 1986:158-206). It was a period in which well-off British people could still speak of the masses as 'the great unwashed', a term coined by the English writer William Makepeace Thackeray in his 1849 novel Pendennis (Ashenburg 2008:170). The unwashed masses may have taken offence at this qualification, but, initially at least, had no problem with their bodies and environments smelling less than fresh (Corbin 1986:83). A great social distance separated the elite from those who, when all is said and done, can be termed the domestic natives, being treated and viewed in a manner very similar to the way inhabitants of the British and other colonies were. Language testifies to this. Savages was one of the terms used to denote the 'very poorest' in Great Britain (Smith 2007:280); taking its place alongside those as 'rabble, mob, caste, mass, sheep and herd' (Kildea 2006:11-2).

In the early nineteenth century the well-to-do also discovered shampoo, not for the hair but for the body. Shampoo must be mentioned here because it is a Hindi loan word, meaning massage, and is one of the contributions of the non-Western world to Western hygiene. In the 1810s shampoo entered Great Britain when an Indian immigrant, Sake Dean Mahomed, set himself up in Brighton as a 'shampooing surgeon'. A few years later he opened his Indian Vapour Baths and Shampooing Establishment in the city. Sake Dean Mahomed claimed that the massage and sweating baths he offered cured his clientele, members of the nobility and gentry, from rheumatism and other diseases. His business did not enjoy a promising start. People talked about 'a cheat and a Hindoo juggler'. Whatever the odds he encountered, Sake Dean Mahomed would eventually rise to the position of Shampooing Surgeon to both King George IV and King William IV. He advertised in a book his medical successes, Shampooing, or benefits resulting from the Indian medicated vapour bath, as introduced into this country, by S.D. Mahomed (A native of India), of which the first edition was published in 1822. ${ }^{8}$

Taking their vapour baths and having declared bathing healthy, the elite began to promote washing and hygiene in general, not

8 See www.fathom.com/course/21701766/session5.html (accessed June 2011). Another nonEuropean bathing habit the Turkish bath or hammam was introduced into Great Britain and the rest of Europe in the middle of the nineteenth century (Aaland 1978:5). In Great Britain, it became popular in the Victorian Era (http://en.wikipedia.org/wiki/Hammam accessed June 2011) and others attribute its introduction to the Scottish diplomat David Urquhart and his travelogue The Pillars of Hercules (1850). Urquhart was indeed an enthusiastic advocate of the hammam, suggesting the building of a 1000 Turkish baths in London to 'wage war against drunkenness, immorality, and filth in every shape' (Aaland 1978:48). It may, however, well be that the first Turkish baths in Great Britain were of an earlier date (Smith 2007:206). 
least because they were confronted with among other horrors outbreaks of cholera in European cities. Public bathhouses reappeared, initially to cater to the middle classes. Later industrialists built bathhouses for their labourers, while municipalities took care of the bodies of the poor, probably as was the case in the Netherlands first in the cities and later on in the countryside (Smith 2007:243, 281-2; Perrot 1987:18-20, 118; De Leeuw 1993:176, 262, $464)$. But it was only around the middle of the nineteenth century, when the upper and middle classes could no longer stand the stench emanating from the others, that the idea that washing was hygienic and healthy gradually gained ground in wider society. ${ }^{9}$ Personal cleanliness developed into a real mania in Europe and the United States in the early twentieth century; ${ }^{10}$ almost inevitably also resulting in a fair amount of scholarly studies about cleanliness and about how people reacted to smelly armpits, bad breath, and other bodily odours (Soo and Stevenson 2007). The rise of such attention is recent. Norbert Elias, who writes about spitting, farting, blowing one's nose and other such things in his study of 1939 Über den Prozess der Zivilisation, hardly mentions bathing except for one lengthy footnote. When he does, it is to illustrate changing European attitudes towards nakedness. He is sure that up to the second half of the eighteenth century, hygiene enters the picture only as a post-factum discovered justification for changing social habits (Elias 201:176, 178, 783). There is no word in Über den Prozess der Zivilisation about such core elements of personal cleanliness as the use of soap and the changing of underwear.

\section{THE ANGLICIZATION OF THE BRITISH RULING CLASS IN INDIA}

In the colonies another process was taking place. At the end of the eighteenth century a campaign was launched by the newly emerging colonial elite to 'Anglicize' the British ruling class in its colonies, allowing for all kind of prejudices, among them those about cleanliness to gain force. In India the advance of the new elite spelled the

9 Of course this was a gradual process. The idea that bathing could endanger one's health or bordered on immorality took a long time to die (De Leeuw 1992:354). Another point still stressed by some was that the wearing of clean underwear was more important than a frequently washed body (Perrot 1987:113).

10 Ideas of personal hygiene spread over the world. In the colonies hygiene campaigns to combat diseases became almost endemic. As the story of the Thai farmer and his struggle with a modern, Western toilet indicates, such campaigns did not leaving independent countries like Thailand and China unaffected (Hell 2007:133-73; Dikötter 2007:205-9). 
end to generations of British men who had happily and comfortably adjusted to the local high-life in the seventeenth and the eighteenth century; some of whom are so vividly described in studies by William Dalrymple (2002) and Maya Jasanoff (2005). Such people, then on their way out, had had a keen interest in local culture and did not speak of Indians or the natural environment being dirty. The Asians with whom these men mingled had taught them to bathe and to enjoy it. They had also made them familiar with smoking a waterpipe (hookah) and other local pleasures. Dalrymple (2002:36) writes that it was Indian women who had introduced British men to 'the delights of regular bathing'. Others among their compatriots had not yet come so far. On their return home, such bath-taking British were 'scolded by their less hygienic compatriots' and were considered to have become 'effeminate' (Dalrymple 2002:36).

Initially, such European bath lovers may only have been a happy few. In Southeast Asia, other Europeans had almost certainly also been shown the way to the bath by native women, but in the seventeenth and the eighteenth century it probably took at least one generation before Europeans in the tropics could shed what the Dutch historian De Haan (1922, II:80) has called their hydrophobia. Describing life in Batavia in the middle of the eighteenth century, he writes that 'born Dutchmen' detested bathing as did the Portuguese. They left this to the ladies, who were of local or mixed descent (De Haan 1922, II:80). Jean Gelman Taylor (1983:1010) also notes that European men in Batavia 'refused to adapt to the Asian custom of frequent bathing'. What Europeans did was to put on clean clothes regularly. A group which certainly did not like bathing were European soldiers. Around 1750 it was deemed necessary for health reasons that soldiers in Batavia took a bath once every eight or ten days. The order to bathe must have led to some grumbling and unrest. Whatever the reason may have been, and of this we cannot be sure - perhaps the explanation is that their officers also suffered from De Haan's hydrophobia - in 1775 it was decreed that soldiers should not be forced to take a weekly bath (De Haan 1922, II:80-1).

As in Europe the change in favour of taking a bath among Europeans in the tropics came in the middle of the nineteenth century. For Batavia we have an observation by the German author of travel books, Friedrich Gerstäcker (1855:420-2), to substantiate this. In the 1870s male Europeans, including those staying in hotels, in Levuka in Fiji took a bath before breakfast and before dinner in water pools or in the river. 'On they came, young and old, planters, merchants and sailors; in a word, all the white men in the place - sometimes single, sometimes in twos or threes, carrying soap and towels, till there could not have been fewer than forty to fifty round the larg- 
est pool.' (Forbes 1875:26.) About European females the author remains silent. Not everybody was suddenly converted and access to water was a factor that could make a difference. In the southern part of nearby Taveuni Island, where people were dependent on rain for their water supply, settlers did not bathe; as the owner of the local hotel explained, 'we don't do much washing here' (Forbes 1875:50).

In Fiji the Islanders - using their own soap made of the rind of a fruit species or of alkaline earth - had their own bathing places, separate from those of the Europeans (Forbes 1875:26). This is indicative of another change which had set in earlier. At the close of the eighteenth century and early in the nineteenth century, Europeans in British India who had adjusted themselves to Indian life and their Eurasian offspring fell victim to a change in the British attitude towards the East and its inhabitants. European men who did not conform to the new standards of Britishness were being eased out of the colonial elite. Often European women are blamed for this, but one of the decisive factors which made this change in attitude possible was the growing influence of Evangelicals, or what we nowadays would call the religious right. The Evangelical Movement was born of a reaction to the Enlightenment and, in their dealings with other religions and cultures, its protagonists often usually showed a rigid and uncompromising attitude. They thought that conversion to Christianity, read Protestantism, and the expansion of Western civilization would free the non-Western world from its backwardness. This also meant that Evangelicals were adamant that young impressionable British minds should be shielded from the harmful influence of native society. At home, leading members carried great weight in British politics and in the Court of Directors of the East India Company. In India Evangelicals were well established in the top positions of the East India Company administration and its army. Their disdain for what we nowadays call Orientalism (Fry 2001:202), the preponderance of power they gained in ruling British India, and the harm they did to the training of aspirant employees of the East India Company and to the study and appreciation of local society and culture are well documented (Fry 2001; Kopf 1995; Trautmann 1997). Celebrating temperance and cultural superiority, Evangelicals and their kindred spirits were, as are many others who think that they can save mankind, in the habit of banning things. It did not take long for the consequences of their influence to become visible. European East India Company servants were no longer allowed to don Indian dress and by the 1820s it had become 'the extremity of bad taste to appear in anything of Indian manufacture' in European circles. Army officers were forbidden to participate in Indian festivals. (Dalrymple 2002:50; Spear 1998:142). 
Evangelicals were not the only group responsible for the shunning of native society, but they were a major driving force. Nevertheless, this does not preclude the fact that they had some sensible ideas. William Wilberforce, the great abolitionist, was a prominent Evangelical. Unfortunately Wilberforce's views about India were less laudable. He was among those - and his words carried weight - who argued that 'the Indian family was a source of moral decay' (Trautmann 1997:17). He also made no secret that he believed that the conversion to Christianity of the Indian population was more important than the abolition of slavery (Gilmour 2005:12, 102). Being a man of authority, he was one of the persons responsible for the opening up of India to missionary activities.

\section{RAFFLES'S CIVILIZATION MISSION}

During the British Interregnum between 1811 and 1816, the new British notion of European superiority was disseminated to the Netherlands Indies. One of the persons responsible for this, the British Lieutenant-Governor of the Island of Java and its Dependencies, Sir Thomas Stamford Raffles (1817, I:353-4), certainly did not consider the Javanese dirty. He praises them for their cleanliness; significantly mentioning as an exception: 'the higher classes, and especially those who mix with Europeans'. It is one of the rare indications of the fact that acculturation can work both ways and that it cannot be precluded that contact with a European lifestyle caused at least some members of the non-European elites to lower their standard of personal cleanliness. These exceptions apart, the Javanese took meticulous care of their physical hygiene. The common Javanese who bathed, Raffles wrote, once a day or once in the two or three days were 'more clean than the Chinese and even the European', although 'he would suffer by a comparison in that particular with the natives of Western India'. ${ }^{11}$ The one thing Raffles did not like was the way Javanese groomed their hair. Javanese 'abundantly oil their hair, which among the common people, on account of its length, is too often filthy in the extreme' (Raffles 1817, I:353-4).

11 Not everywhere in India was frequent bathing the norm. An English lady, Mrs Meer Hassan Ali, who had married an Indian Muslim, reported about life in Lucknow in Northern India in the 1830s that the local women might not change their clothes and underwear for a week, and usually would also bathe once a week. Around the same time, a Muslim scholar, Jafar Sharif, discussed the pros and cons of bathing each day, concluding that taking a bath on Friday removed all sins (Tillotson 1998:22, 47-8). 
During his lifetime Raffles was hailed as the epitome of enlightenment. Nowadays he still is and Raffles certainly worked within the tradition of an illustrious group of late- eighteenth-century East India Company administrators-cum-scholars who included the GovernorsGeneral Warren Hastings and the Marquis of Wellesley, and above all Sir William Jones, the founder of the Asiatick Society of Bengal. Nevertheless, he was a different breed from those British who preferred an Indian way of life. He is always portrayed wearing respectable Western garb. Among other things, Raffles' attitude towards religion was much less relaxed (Dalrymple 2006:64-6). Though in his early years not a very religious person, in later life, probably succumbing to Evangelical influences - he and Wilberforce became close friends and after Raffles had settled in England even next-door neighbours and perhaps to those of his wife, Olivia Mariamne, who was a devout Christian, Raffles began to take religion seriously (Aljunied 2005:557; Miller 1966:118-202). He was transformed into an advocate of missionary work, sure in the conviction that Western civilization was superior to that of other cultures (Aljunied 2005:60-4).

Another characteristic of Raffles was that he was very British, or maybe it was his wife, Olivia Mariamne, who was. A publication from 1930 praises her for having rid the European ruling class in the Netherlands Indies of 'a number of less reputable customs and peculiar imitations of native ways' (Van de Wall 1930:3). Before the British Interregnum the British fashion of 'distancing' themselves from local society and culture had not yet reached the Dutch possessions in Asia. Writing about Malacca in 1811, Collis (1966:50) concludes that the 'Dutch mixed more with local inhabitants and met them on a greater social equality than the English at this period and later'.

In Java the Dutch administrators with whom the British had to co-operate whether they liked it or not had to be converted. Olivia Mariamne Raffles appears to have been the motor of a British campaign to civilize the Indo-European wives of the most senior Dutch civil servants who happily chewed betel and dressed in what the British though resembled underwear, namely sarong and kebaya. The fact that these women were not white but Indo-Europeans only added to the dismay with which the British officers and their British wives regarded them. ${ }^{12}$ Somehow, in about a year and in spite

12 Taylor 1983:96-100. In Malacca, the British had encountered a similar situation. Reaction there had been different. The Earl of Minto, Governor-General of India, described the Eurasian girls he met here during a ball in 1811 as 'intensely and beautifully brown', and admired their flirting (Collis 1966:49-50). Some of the younger ladies were dressed in 'English' fashion, but also present were some older ladies dressed in the 'Malay loose gown' and chewed betel. In Bogor, Minto was less flattering, the reason being that most of the Eurasian ladies he saw there at a ball were fat (Collis 1966:65; see also Taylor 1983:97). 
of great opposition, Olivia Mariamne Raffles succeeded in her aim or, as it was recorded in the not impartial Java Government Gazette in 1812: great 'improvement has been introduced in respect to the attire of the Dutch ladies since the British authority has been established. The cabaya appears now generally disused and the more elegant English costume adopted.' (Van de Wall 1930:5.) The same opinion was expressed by Major William Thorn (1815:248) who noted down that the Batavian women 'adopted the fashionable habiliments of our countrywomen, and in their manner as well as dress they are improving wonderfully'.

After a few years the British left Java again. English dress and the idea of Western superiority, of which soap was later to become a small and insignificant element, were there to stay, and probably even without the British Interregnum would have been embraced by the Dutch in the Netherlands Indies. Differences remained. The change in the British attitude towards the local population in their colonies, which was gaining momentum at the turn of the nineteenth century, as said, owed much to Evangelicals and their intemperate religious zeal. In the Netherlands, this form of Christian pressure group failed to muster the same amount of influence it had in Great Britain. Missionaries were not allowed to work in Muslim regions, where anyway as everybody knew, perhaps with the exception of the missionaries themselves, their rate of success would be minimal and fierce and violent discontent could easily be the result. So, the observation made in the 1850s by Friedrich Gerstäcker (1855:440), that the Dutch in the Netherlands Indies stood out for their 'tolerant and sensible freedom of religion' may not have been an unsubstantiated remark.

SOAP AS THE MARKER OF CIVILIZATION

Oblivious of their own recent history of tending to wallow in dirt and enthusiastically embracing the newly rediscovered notion of cleanliness, Europeans and Americans began to use taking a bath as a yardstick to judge others. Nevertheless, it was soap, not bathing, which made a person civilized. There is some logic in this. As the first Europeans who sailed to Southeast Asia did not fail to notice the Malays, the Javanese and other people in Southeast Asia did bathe, and this more times a day than a Westerner would do. All this was inessential. It did not count. By the end of the nineteenth century the belief in the dirty native and the dirty servant seems 
to have become widespread, at least among the colonial British. ${ }^{13}$ Imagine the bewilderment of a three-year-old girl in India in 1880 who had been told by her parents that she should not talk to one of the servants, the poor man who kept the punkah, the fan, moving, because he was dirty. After a while she returned to her mother saying 'He has bathed' (Buettner 2004:53). And, some forty years later it is recorded in a manual about The home and health in India and tropical colonies that Indian servants differ from the British in their 'standard of personal cleanliness' (Platt cited in Buettner 2004:39).

Soap may have made the difference. In Malaya, The Straits Independent and Penang Chronicle of 23 May 1894 contains a report by George C. Bellamy, the District Officer of Kuala Selangor about his trip to Ceylon. In Colombo he visited a government milk factory. What he saw impressed him. Penang should also have such an enterprise. With its 'abundant rainfall, and the consequent richness of its pastures', it was actually 'much better situated for such an industry' than Colombo. Away, he wrote, with the '[f] ever and other diseases [which] lurk in our milk cans'. And think about the spin-offs: the production of cheese and butter! Health and profits loomed, but this could only be realized under European management. When such a statement is made, it might have been expected that a discussion of the managerial qualities of Europeans, Chinese, Indians, and Malays, the usual procedure when non-Europeans were considered for the first time for a profession which up to then had been closed to them. Such a debate would often end with the conclusion that non-Europeans lacked the right mentality, muscular strength, or proper education to qualify them for the job. This time there was nothing of the sort. Management of such an enterprise should be in the hands of 'people to whom cleanliness is a virtue'. This assessment disqualified all non-European residents: 'Chinese, Klings [Indians] and natives will bathe, sometimes as many as three times a day, but they are none the cleaner, they smell none the sweeter for all that. The few buckets of water they throw over themselves on these occasions does not wash their dirt away.'

Is this because they did not use soap? Bellamy does not mention it. Nor does the story about the Indian servant give any indication. Bellamy does give other reasons the natives were denied their cleanliness. The clothes they put on after they had taken a bath were 'as filthy as ever'. In their houses 'the accumulated dirt of twenty years may be

13 There is a very good chance that the idea of the unclean servant was constructed upon an older European tradition about domestics being dirty. In the second half of the eighteenth century and well into the nineteenth century, the well-to-do in France and Germany considered their domestic servants dirty and complained about their smell (forcing some of them to take a bath). Some contemporary authors suggest their readers should keep domestics out of the children's nursery or bedroom and to air the rooms they lived in (Corbin 1986:189, 192, 203, 214). 
scraped off the walls, to say nothing of the floors on which they sleep'. Evidently, Bellamy does not agree with his contemporaries, who - it must be admitted - did exist, who considered Malays to be personally clean because they washed themselves. He exclaims: 'Away with this delusion; cleanliness, like its neighbour godliness, is a different thing altogether, a thing which only a white man can appreciate at its proper value'. His conclusion is clear. A European should be appointed the manager of the milk factory. Once this had become reality 'our stinking Kling milkman would then become a thing of the past'.

We can expand the story. Bellamy was not alone in his observations. Howard Malcolm (1839:192-3), travelling through Southeast Asia in 1837 as representative of one of the larger American missionary societies, observed that in Burma people could always be seen bathing, but he continues by writing that "[v]ery little is accomplished towards removing the filth from their bodies by their daily ablutions, as they seldom use soap...'. Malcolm (1839:192-3) also informs us that those bathing were a very small proportion of the whole population and that the washing of clothes was 'done only at very distant intervals'. It is as if he is taking pains to assure his readers that those Burmese were actually a filthy lot. Malcolm's words are a remarkably early denunciation of the soap-less. Mass-produced soap, we must remember, is a relatively new commodity in Europe and the United States. It appeared on the market only in the second half of the nineteenth century. When Malcolm wrote down these words only a very select group of rich Europeans and Americans could afford to wash themselves with soap.

Linking soap and civilization only really began to pick up in the 1880s when advertising in newspapers and magazines took off. Here the history of soap and that of advertising meet. The person who brings them together is Thomas J. Barratt who had fortuitously married the great-granddaughter of the founder of the Pears' Soap Company. Barratt is hailed as 'the father of advertising'. He was also responsible for many of the advertisements depicting cleanliness and soap as the embodiment of civilization.

Among the people who, it was suggested, might benefit from the introduction of soap were the inhabitants of the Philippines, or rather the Americans who had just taken over the colony from Spain. In 1899 Pears' Soap had a piece of advice for the American administration in Manila. Teaching the virtues of cleanliness was the first step towards lightening 'The White Man's Burden' (the title of the poem written by Rudyard Kipling to persuade the United States to take possession of the island group and prevent a Filipino-run independent state from coming into being). How better could this be done than by distributing soap? The 1899 'Admiral Dewey' advertisement leaves no doubt about this (Figure 2). In 


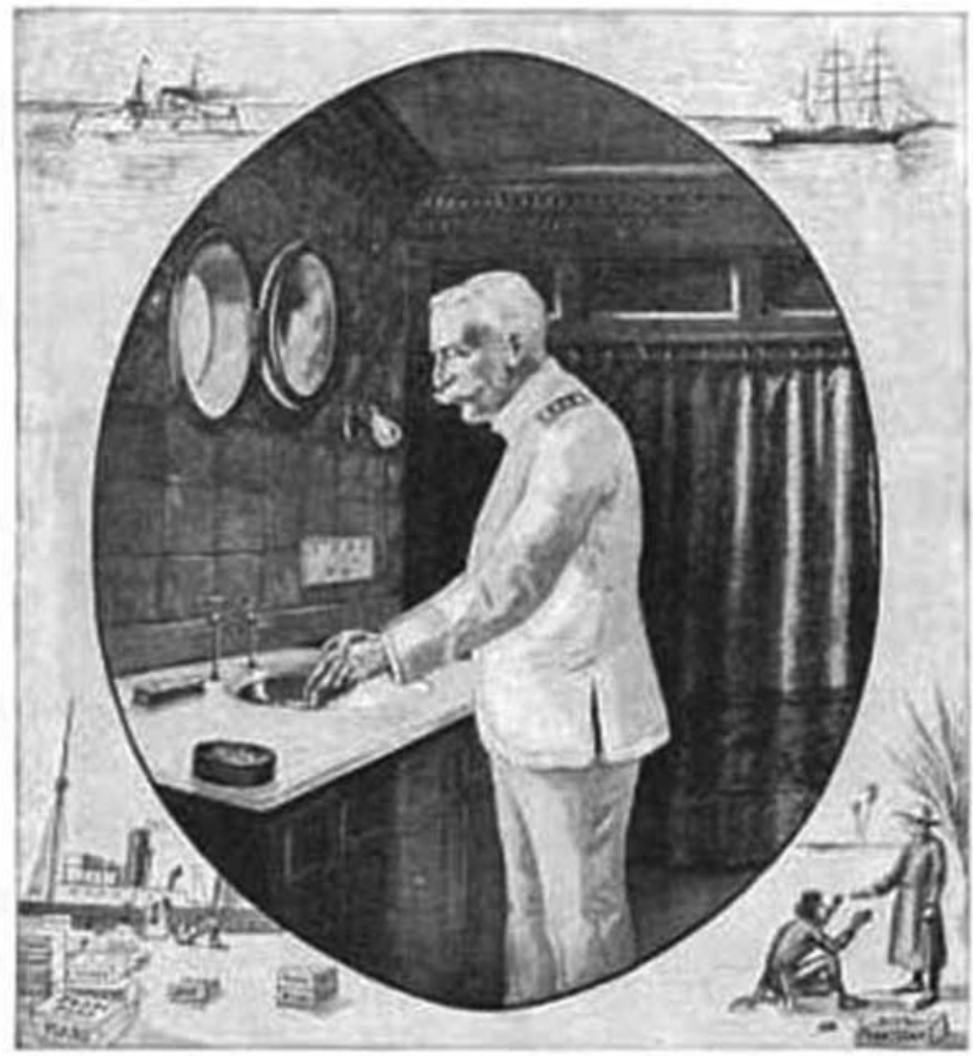

The step towards lightening The White Man's Burden is through teaching the virtues of clearlines

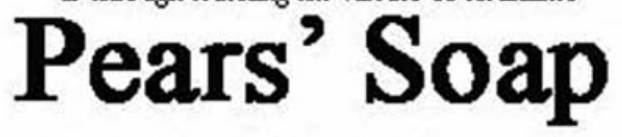

is a potent factor brightening the dark corners of then earth as civilization advances while amongst the cultured of all nations it holds the highest place -- it is the ideal toilet soap.

Figure 2. 'The white man's burden'. A Pears' Soap advertisement, 1899. 
the bottom-right corner a person can be seen presenting soap to a figure, and I suspect it is a Moro, a Muslim from the South, who, to make the contrast the greater, has a Neanderthal appearance.

In contemporary British eyes, Boers were no better than uncivilized natives, and suffered a similar fate. Boers even shared the misfortune of being put on display with non-Western people. In May 1899 an exhibition in London presented 'a horde of savages direct from their kraals, comprising 200 Matabeles, Basutos, Zwazis, Hottentots, Malays, Cape and Transvaal Boers' (Shephard 1992:97). In an account of the Boer War dating from 1900, the Boers, who inflicted a number of humiliating defeats on the British, are not only portrayed as cowards - they are also dirty: 'The Boer cannot stand steel. He has as great a horror of it as he has of soap and water and a change of clothing.' (Neilly cited in MacDonald 1994:39.) Unfortunately for the British, in the rest of Europe, the United States and in what one Dutch author rather enigmatically described as 'the civilized non-British part of Asia', the Boers were hailed as heroes (Andriessen 1904:490). As such they were eligible to appear in advertisements, including those for soap (Figure 3). Nevertheless, it has to be admitted that in the case of the Boers there may be some truth in the observations that they were not exactly clean. Maurice Nyagumbo, a politician from Zimbabwe, one of those who in their youth had had to sing that they were dirty, recalls a visit to the Orange Free State in the 1930s. He notes that the Boers were 'completely oblivious to' cleanliness: 'The whole building was infested with swarms of flies. Women came into the dining-room with hair falling everywhere. People blew their noses and spat everywhere in the dining-room.' (Burke 1996:197.)

But did the Boers deserve soap? The answer is ambiguous. Emily Hobhouse, one of those British ladies determined to do something about the plight of Boer women and children interned in concentration camps during the Boer War, was appalled at what she saw there. One of the matters which especially offended her, and she took pains to emphasize this, was that there 'was no soap provided' (italics hers; cited in Pakenham 1992:506). Initially the authorities refused her request to send soap to the camps, arguing that 'soap is an article of luxury'. ${ }^{14}$ In the end, the women and children were allowed one ounce of soap a week per head (Pakenham 1992:506).

The British elite and those Britons who ventured to the East or to Africa, as may have become evident by now, nurtured their own peculiar worldview. The Boers were not the only Europeans who were low on the scale of British appreciation. They shared this fate with the Italians and the Irish. In 1846 a young British Roman Catholic man found Italians 'a people of dirty habits, offensive 


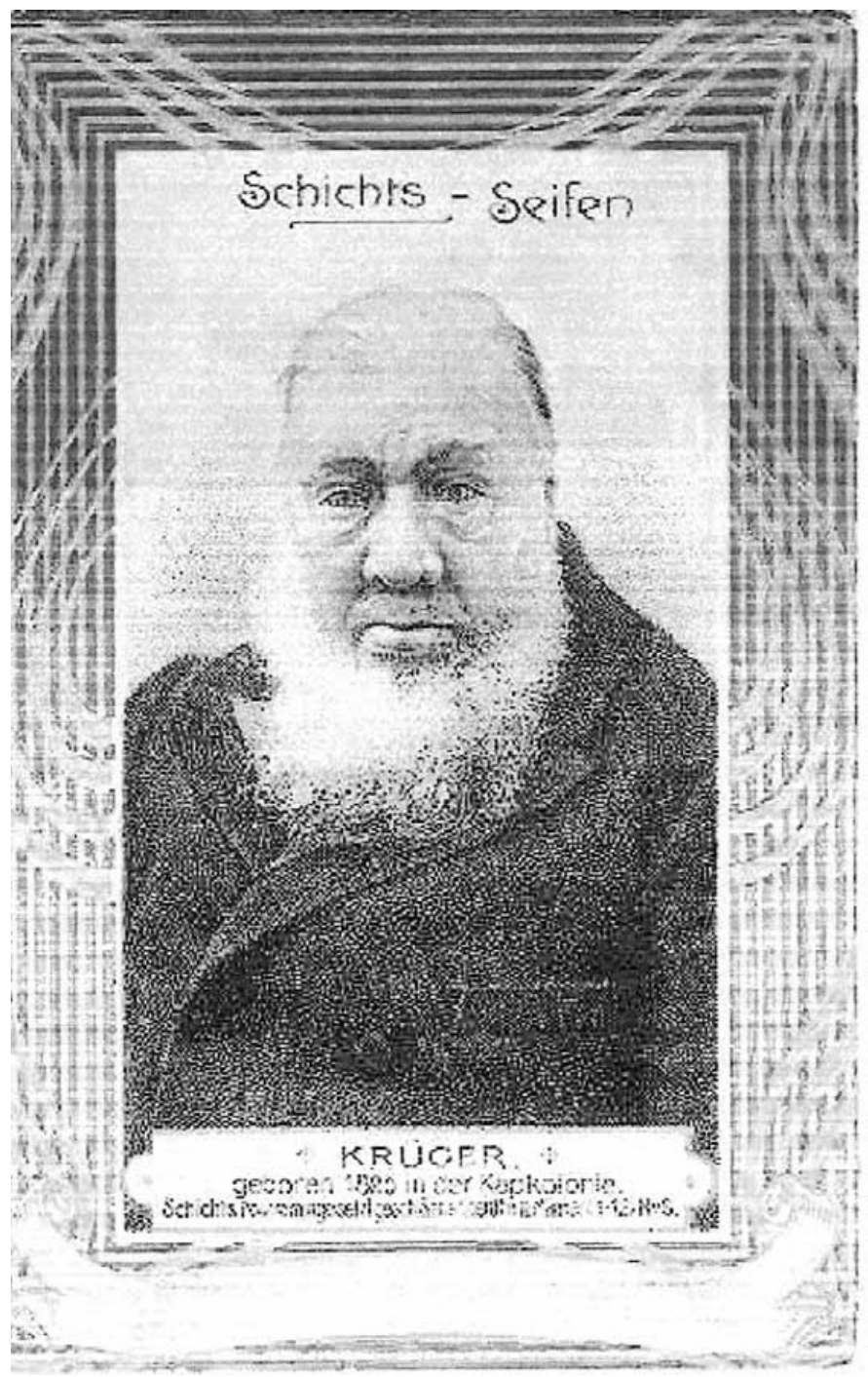

Figure 3. 'Kruger'. A Schichts Seifen advertisement, 1904. 
those who came from a nation that valued cleanliness' (Newsome 1997:96). In 1880 a Belgian economist, Gustave de Molinari, observed that British newspapers 'treated the Irish as an inferior race - as a kind of white negroes' (McClintock 1995:52). In fact, it could be even worse. The qualification of the Irish by the novelist Charles Kingsley has become notorious. In 1860, in a letter from Ireland to his wife, he called them human or white chimpanzees (Curtis 1968:84). Being branded inferior, the Irish were also considered to lack hygiene (Maxwell 1999:31). In this respect the British valued the Dutch and the Swiss and above all the Germans more (Newsome 1997:94). That is why while The Malay Daily Chronicle stated on 14 October 1912 that Great Britain could 'claim the pioneer's honour' in the study of hygiene, the newspaper had to add that Germany had 'introduced more method into its administration of a Department of Public Health'. Competing for political, economic and cultural supremacy, Germany and Great Britain were also each other's rivals in the field of the promotion of hygiene. Victorian Britain and Wilhelmine Germany produced the most beautifully ornamented and decorated lavatory pans (Corbin 1986:222).

Of course, Anglo-Saxons were not alone in stating that natives were dirty. Frenchmen were very apt to make sweeping statements about the inhabitants of Indochina. In 1886, it was observed that an Indochinese was 'of disgusting dirtiness, devoured by vermin and eaten away by skin diseases, covered in stinking rags ... [he] sweats filth and ignoble wretchedness through his very pores' (Aldrich 1966:202). In a similar vein, in Le Figaro a French naval officer described the inhabitants of Vietnam as 'apelike' and smelling of 'yellow sweat, incense and filth' (Spence 1998:149). In the Netherlands Indies washing and the use of soap also became part and parcel of civilization. In August 1914, just after the outbreak of the World War One, a number of native policemen from German New Guinea, their uniform consisting of a cap and a loincloth, fled to Hollandia. In the newspaper De Locomotief (24-8-1914) there is a report of what happened to them. After being properly dressed in a jacket (jas toetoep), trousers, and a planter's hat - one of them even donned boots - they visited the Assistant-Resident and asked him to give their 'naked wives' a make-over. Subsequently, the women were given a 'thorough bath with a piece of soap' and were dressed in sarong and kebaya. What had been done was once 'again a masterly example of civilization work', the report concluded.

\section{CLEANLINESS AND GODLINESS}

These examples indicate that real cleanliness was becoming the preserve of Europeans, and, it has to be added, of Christianity. Soap 
became an attribute of God - or rather the Protestant conception of Him. Natives and Muslims were either less clean or definitely dirty.

Cleanliness and godliness were presented as the two sides of the same coin. 'Cleanliness is next to godliness' became the slogan in the Anglo-Saxon world in its attempts to induce those poor souls at home and abroad who had not yet discovered the virtues of the new standards of hygiene to wash their bodies and their clothes. This Jewish saying was first made popular among British Methodist by one of the founders of this movement, the Englishman John Wesley (1703-1791). ${ }^{15}$ It is a far cry from the idea that a filthy body was a sign of religious devotion advocated by the mediaeval saints.

Instead of quoting from Jewish sources, John Wesley may have also turned to Islamic tradition according to which the Prophet Muhammad said that 'cleanliness is half of faith'. Muslims performed their very visible ritual ablutions before prayers; and were required to wash the whole of their body after sexual intercourse, though the latter stipulation was probably not known by the Europeans and Americans visiting Muslim regions. Such religious commands to observe cleanliness did nothing to save Muslims from being regarded as dirty by Christian travellers. The British poet and traveller, James Elroy Flecker (1884-1916), wrote that he hated the Orient and that thank God the Lebanon was Christian (Kabbani 1991:28). Flecker's lamentation is akin to the observations made in the 1830s by the American John Lloyd Stephens. He hailed the 'privileges of civilization' after having encountered 'an utter lack of hygiene' in the Middle East (Oren 2007:159). Stephens's observation encapsulated the American experience in the Middle East. Many of his fellow Americans who visited the region were missionaries or pilgrims with a Christian background. Their reaction, especially to what they saw in Palestine, the Christian Holy Land, was, as Oren (2007:140) captured this in words, 'a blend of aesthetic disgust and spiritual elation'.

Being Americans, they, and Mark Twain and Theodore Roosevelt were among those who did, thought nothing of the River Jordan of which, reading the Bible and listening to sermons, they had formed their own grand image. The river was simply too small (Oren 2007:134, 242, 310). Another, the explorer William Francis Lynch, exclaimed that the 'curse of God' had surely fallen upon the Dead Sea (Oren 2007:139). Mark Twain, whose description of Syrian men includes the words rags, dirt, and sores (Oren 2007:242)

15 It is certainly possible that Wesley's cleanliness was still a spiritual cleanliness. He uses the phrase one of the first times in his sermon 'On Dress' he gave on 30 December 1786. In it he fulminates against the wearing of jewellery and costly clothing. Attire should be cheap and plain. Wesley speaks about neatness of apparel, but may have meant this in the sense of being without adornments. 
must be counted among those explorers, travellers, and missionaries about whom the first question which enters one's mind is: why did they do it? He wrote that a death sentence was preferable to residence in the Middle East (Oren 2007:240). By World War Two the American outlook did not seem to have changed much. General Dwight D. Eisenhower liked Algiers, it was a 'beautiful and picturesque' city, but he did complain about the Arabs who seemed 'to have very little regard for personal cleanliness' (Oren 2007:464).

Some Dutch persons were guilty of similar perceptions. Describing a journey into the interior of South Sulawesi in 1856 B.F. Matthes (1857:13) writes: 'I did not like the trip at all. Lake Tempe, which is so highly praised [and is nowadays a tourist attraction], was completely as are indeed the land and people - as it were, strikingly squalid'. Other regions where the elite and the 'advanced', the new intelligentsia, had begun to assimilate some parts of the European way of life suited such persons better; especially when the change implied a turning away from the culture of Islam. Around 1900, writing about North Sulawesi another Dutchman, N. Graafland (1898, I:3) complained that while 'the Minahassa may already be counted among the countries where Christianity and civilization have obtained a firm footing [...] in Gorontalo one is transported back into a totally Mohammedan world, with much that revolts'.

Soap, Christianity, and civilization became intertwined, they merged into one entity. In the 1880s in a Pears' Soap advertisement the Reverend Henry Ward Beecher, a famous American Evangelical clergyman and a brother of Harriet Beecher Stowe, the author of Uncle Tom's Cabin, exclaimed that 'if cleanliness is next to Godliness, Soap must be considered a Means of Grace, and a Clergyman who recommends moral things should be willing to recommend Soap'. Not insignificantly in view of the expanding Evangelical flock in America, and in an example of denominational shopping in the material sense of the word, he adds in the advertisement that he had been told that his 'recommendation of Pears' Soap has opened for it a large sale in the United States'. The link is clear. In the 1930s, in its campaign 'instructing Natives in Hygiene', the Southern Rhodesian Missionary Conference concluded that the natives should be taught that 'cleanliness is next to Godliness' (Burke 1996:194-5).

Another region featuring in the Pears' Soap advertisement was China. (Figure 4) Missionaries may have 'adopted native dress, "pigtail" and all, to avoid undesirable attention among the vast hordes of interior China', but, an advertisement from 1910 informs us the 'exceedingly neat and cleanly appearance of these white people in the native dress' could be attributed to the use of Pears' Soap. Always rely on Pears' Soap: 'If anything can civilize and Christianize China, Pears' Soap and the missionaries will'. 


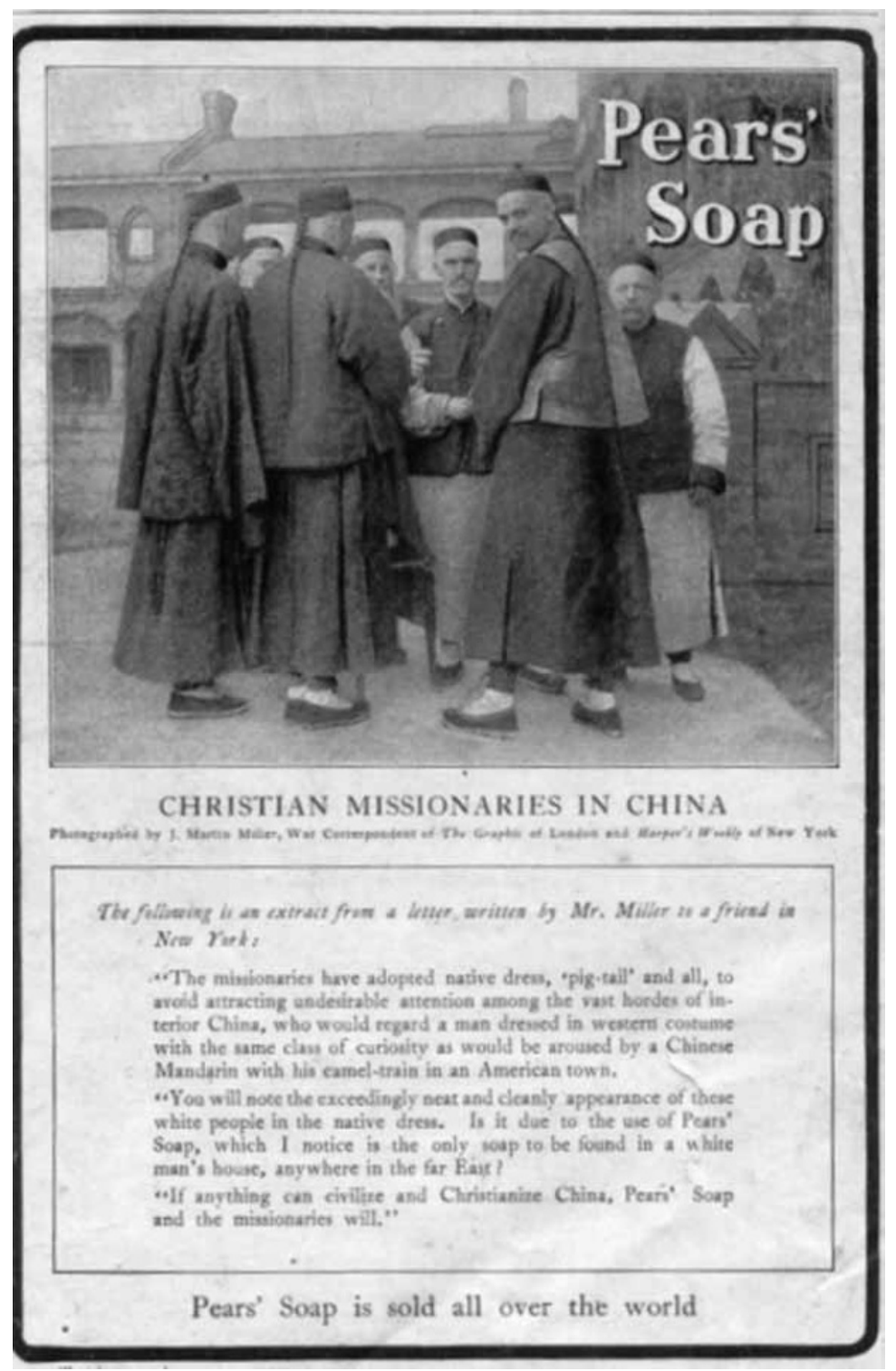

Figure 4. 'Christian missionaries in China'. A Pears' Soap advertisement, 1910. 
In the Netherlands Indies, the association of soap with Western cleanliness was more muted. The link connecting the two in this case is that icon of cleanliness, the proverbial Dutch housewife (Figure 5). What better image to sell soap, in this case Sunlight soap, than that of a Dutch lady carrying a laundry basket filled with freshly washed clothes climbing a ladder? The advertisement in the Malay-language Bintang Soerabaia of 9 January 1918 urges its readers, who must have been Indonesians, Eurasians, and assimilated peranakan Chinese, to buy Sunlight soap, not least because, as we read, it makes a heavy task lighter and easier. Why the Dutch housewife had to climb a ladder remains a mystery, and what exactly she is wearing on her head also gives some cause for conjecture, but the advertisement is also peculiar in another respect. In the Netherlands Indies Dutch women did not do their own washing. They had their native servants to perform this task. But, on second thoughts, again with the exception of the ladder and the headdress, is the advertisement as odd as it appears at first glance? It responds to the association of European habits with a modern way of life which was then gaining ground in Indonesian society. An indication that this was indeed the case and that soap was indubitably considered to be one of the material artefacts of modernity is that, among the many pen-names used by Indonesian contributors to Malay-language newspapers, we also find the English name 'Sunlight Soap' alongside that of Nieuwe Pakkendrager (New Wearer of Suits), and admittedly also Steeds Lijder (Eternal Sufferer) and Bin Troelala.

Some authors have stressed the racial message of soap advertisements in the colonial era. Anne McClintock (1995:209) discusses the advertisements within the wider context of 'commodity racism' and 'commodity jingoism'. Garvey (1996:203) argues that 'black characters appeared in contemporary soap advertisements only as a racist joke, to demonstrate the claim made in the advertisement that black skin could be scrubbed white by the product'. Others have drawn a similar conclusion; and it has to be admitted there were indeed some very dubious advertisements (see also Prabasmoro 2003) (Figure 6). Nevertheless, we are faced with the fact that soap and taking a bath removes dirt and that a convenient way to visualize this is by turning a black person into a white one.

The Bintang Soerabaia advertisement with the Dutch housewife up the ladder indicates that the relationship between soap and race is more complex. Using soap made Indonesians white in the metaphorical sense. It was a tiny step on the road towards emancipation; just as was donning Western attire in the first decades of the twentieth century. The colour of the skin was less important. Dressing in the Western fashion allowed Javanese to enter the European public sphere, which, in the context of the Netherlands Indies, meant 


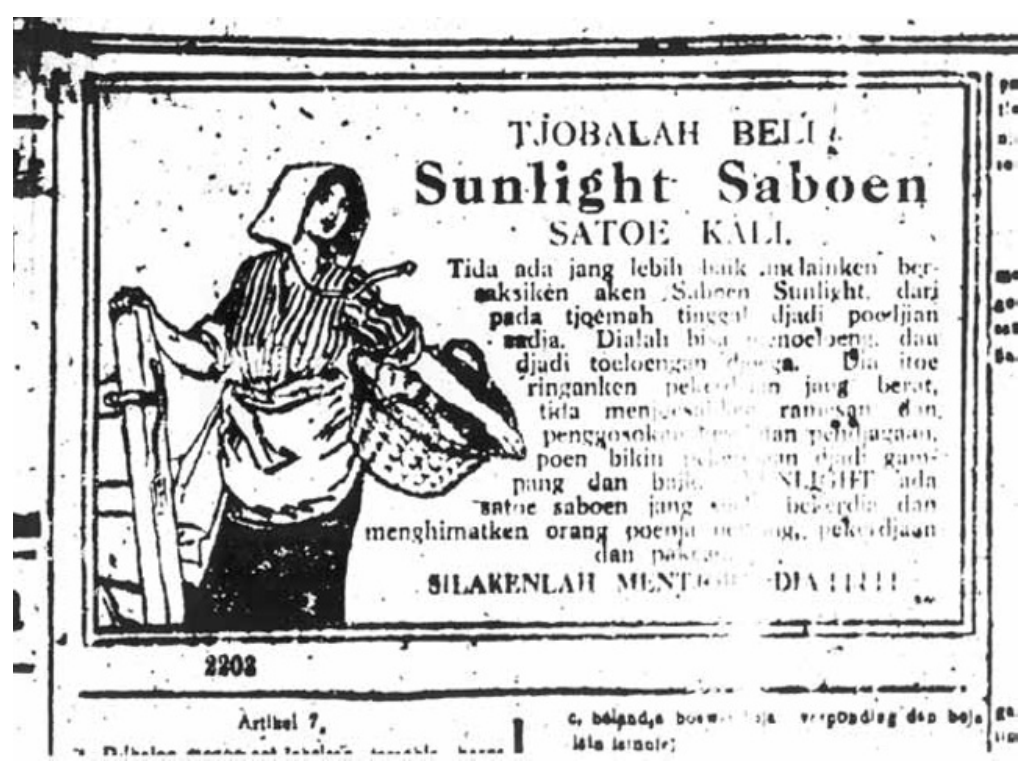

Figure 5. A Sunlight Soap advertisement, 1918

the European/Eurasian public sphere, from which a preference for Javanese clothing would have banned them. Dressed in a Western fashion, they also were treated in a much friendlier manner by Europeans than were they to have approached the latter in Javanese clothing. They could quite literally leave their native compartment and travel European class at the railways. There was one drawback Indonesians in European garments were not allowed to buy the cheaper ticket reserved for 'Easterners' (Van Dijk 1997:58-71).

Soap is not mentioned terribly often in their evaluations of the level of civilization of the other by Europeans and Americans. As Bellamy's statement about the milk factory and Malcolm's remarks about Indochina indicate, it is easier to ignore the body and concentrate on unwashed clothes and perceived slovenliness in houses in efforts to brand non-Europeans filthy. This seems to have been the ultimate technique which allowed Westerners to maintain the top position 


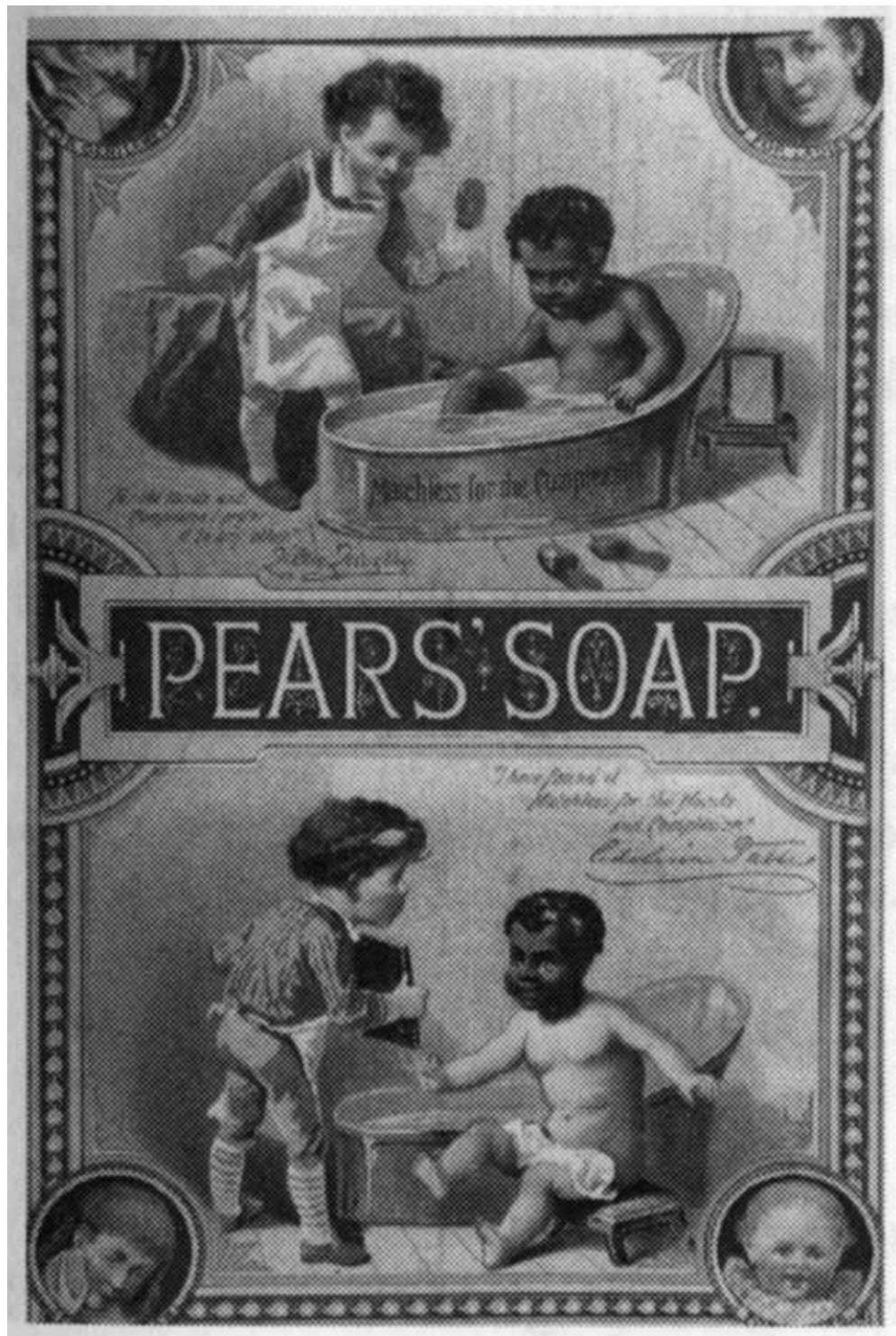

Figure 6. Black turning white. A Pears' Soap advertisement. 
on the global scale of cleanliness. When all is said and done, even Japanese, the nation certainly well-known, perhaps even famous for the frequent bathing of its inhabitants, could be disqualified. In 1863 Harper's New Monthly Magazine recorded a statement: 'As far as their persons are concerned the Japanese are certainly a very cleanly people. But this does not hold good of their garments. These are worn day and night, and rarely changed. ${ }^{16}$ (Soap advertising n.d.:1.)

This raises the question: how many times did contemporary Europeans and Americans change their clothes, especially their linen, in those days? In the mid-nineteenth century Europeans in the tropics, at least in Batavia, it has to be admitted, took a bath and changed clothes twice a day (Gerstäcker 1855:420-2). Judging from the advice to nineteenth-century Dutch boarding-school girls that they change their underwear at least once a week, people were not as keen on the daintiness of their garments in a cooler climate (De Leeuw 1992:177). Around 1900, once a week, or perhaps even once a fortnight, may indeed have been the norm among the middle classes in the Netherlands. In rural areas, farmers washed their clothes and themselves much less frequently (De Leeuw 1992:215, 326, 328). Incidentally, changing underwear once a week also was promoted in a fatwa issued by the Russian State-appointed mufti, Gabdulvakhid Suleimanov, on the instigation of the Russian authorities in their campaign to combat diseases in the Ural Mountains in 1849. It was coupled with the suggestion to 'wash once a week in warm water' (Crews 2006:80).

Writing about the portrayal of others as dirty, in one of his books MacDonald (1994:35) observes that the harshest qualifications are reserved for people of a mixed race. He suggests that the 'fear of the other may be expressed at its deepest in things sexual, for the most violent language is reserved to describe those who are thought to be the product of miscegenation'. MacDonald's conclusion is that the 'insistence on the "cleanliness" of the whites and the "dirtiness" of all other races seems in essence to express a fear of things sexual', indicative of 'a culture in which East and West, Light and Dark, were polarised.'

The examples I have mentioned about the attraction of the idea of modernity in the Netherlands Indies, and the possibility for Indonesians to enter the European sphere of life because it had become impossible to differentiate them from the Indo-Europeans indicate that something different was at play. Moreover, MacDonald's remarks concern a British colonial setting. Some members of the British upper and middle classes may have been especially sensitive to racial prejudices; for a long time opinions among the ordinary British were

16 http://www.clas.ufl.edu/users/jshoaf/Jdolls/jdollwestern/Ads/japrose.html (accessed April 2011). 
remarkably broad-minded (See Fischer 2004). It may indeed well be as one author, Garvey (1996:203), suggests that the Pears' Soap advertisements with a racial connotation appeared primarily in Great Britain.

Contrary to what is sometimes assumed, the colour of the skin was much more important to Europeans in British India and Malaya than it was in the Netherlands Indies, where discrimination against Eurasians did take place, but on a lesser scale. Eurasians were legally discriminated against in Malaya and British India, a state of affairs made possible by the fact that formally they were not considered Europeans, but were listed as a separate category in population statistics (De Cock Buning 1916-1917:380). In 1904 and 1910 Eurasians and nonEuropeans in Malaya were denied access to administrative positions in the civil service (Shennan 2000:70). In India, with the exception of the most humble positions, Indian-Europeans had already been barred from 'employment in the Civil, Military, or Marine Service of the [East India] Company' in the late eighteenth century; a fate they shared with respect to the Army and with Roman Catholics. ${ }^{17}$

Dutchmen could gloat over the way Indian-Europeans were treated in British India, which one Dutch author noted in the 1910s was 'shocking according to Dutch standards' (De Cock Buning 1916-1917:380). In India and Malaya the colonial elite was white and being white mattered, very much so also in mixed-race circles. Among mixed-race individuals having a fair complexion was definitely considered a blessing, paving the way for upward mobility. The British detested Indo-Europeans who hid their background in order to advance in society and turned to an investigation of marks on the body which could expose such persons, scrutinizing fingernails and eyes in a failed effort to identify Indo-Europeans who were pretending to be white; a failing which other Europeans and Americans also resorted to on occasion (Buettner 2004:69, 84-5) Even in the Malay Eurasian community 'skin discrimination' could be obtrusive. De Locomotief of 26 January 1917 calls attention to families in the Straits Settlements in which members who had a browner skin were ostracized by their fairer relatives. In the article it was also observed that in the Straits Settlements a marriage between a full-blood European boy and a Eurasian girl was rare and that when it did take place the girl had to have a fair complexion. This, the newspaper concluded, was a very different situation from that in Java, where Eurasian girls seemed to exert a great sexual attraction on European boys.

17 Fisher 2004:79, 201; Dalrymple 2002:50. The ban was formally lifted in 1833 when Parliament ruled "that no "native" of the Company's territories or "natural born subject of His Majesty" would be excluded from any appointment in the Indian civil service or army on the basis of religion, place of birth, descent, or colour' (Fisher 2004:211). 
What is described above seems to be a matter long dead and gone, but occasionally it comes to the surface again. The British, as Jeremy Clarkson not so long ago wrote with his usual sense of humour in his column in The Sunday Times (27-5-2007), still 'harbour a cheery notion that Britain and its people are a shining beacon of hope and goodness to the dirtier and less well educated'. Just how alive such sentiments remain became evident after The Sunday Times had paid attention to Hortense de Monplaisir's book Le Dossier: How to survive the English. In its next issue the paper (11-7-2007) published some reactions of its readers. They had written about Frenchwomen 'with questionable hygiene', a French girlfriend who 'only brushes her teeth every few days', women in France who turned up 'at the beauty salon and have what looks like camembert between their toes', and - a final blow to the French that British women 'may all have huge bottoms' but that the British had proper toilets, unlike the French, "who insist on going by the side of the road'.

In the Netherlands such ideas also persist. A striking example, and I must confess I am still not sure whether this meant to be irony or not, is a letter to the editor published some years ago in $D e$ Volkskrant (16-9-2006). Its sender wrote that it struck him that Muslim terrorists are 'so ugly' and that he 'has never seen an attractive Islamic fanatic, male or female'. His advice is simple: with 'a little more attention to the appearance - such as personal hygiene and pretty clothes - they will go further in the world', and, it is implied, keep them from committing acts of terrorism.

The concept of cleanliness is multifaceted. It concerns the body, attire, the house, the natural environment, and also what is now called the built environment. There are many factors which contribute to the way different people define cleanliness. Class, social status, ethnicity and nationality, religion and religious denomination, medical discourse, and place and time all play a role in shaping opinions about bathing and washing. Feelings of superiority should also not be overlooked. Those who think of themselves as belonging to The Clean may tend to consider cleanliness to be an exclusive characteristic of their own social environment, blinding them to any indications to the contrary. They can also promote their own ideas about cleanliness with religious zeal, without realizing those they see as less clean are not as dirty as they assume. At times such efforts even become inextricably linked to real missionary activities. 


\section{REFERENCES}

Aaland, Mikkel

Sweat; The illustrated history and description of the Finnish sauna, Russian bania, Islamic hammam, Japanese mushi-buro, Mexican temescal and American Indian and Eskimo sweatlodge. Santa Barbara, CA: Capra Press.

Abdullah bin Abdul Kadir

The Hikayat Abdullah; An annotated translation by A.H. Hill. Kuala Lumpur: Oxford University Press. [Oxford in Asia Historical Reprints.]

Aldrich, Robert

1996

Greater France; A history of French overseas expansion. Basingstoke: Macmillan. [European Studies Series.]

Aljunied, Syed Muhd Khairudin

2005

Rethinking Raffles; A study of Stamford Raffles' discourse on religions amongst Malays. Singapore: Marshall Cavendish Academic.

Andriessen, W.F.

1904

Gedenkboek van den oorlog in Zuid-Afrika. Amsterdam: Hollandsch-Afrikaansche Uitgevers, v.h. Jacques-Dusseau.

Ashenburg, Katherine

2008

Clean; An unsanitised history of washing. London: Profile Books.

Barnes, David S.

2006

The great stink of Paris and the nineteenth-century struggle against filth and germs. Baltimore, MD: Johns Hopkins University Press.

Biow, Douglas

2006 The culture of cleanliness in Renaissance Italy. Ithaca, NY/London: Cornell University Press.

Bonacorsi, Paolo

n.d.

Saint Francis of Assisi (English version by Elisa Fiolini) (http://www.assisiweb.com/vita_san_francesco_en.html)

Boogaart, Ernst van den

2000

Het verheven en verdorven Azië; Woord en beeld in het Itinerario en de Icones van Jan Huygen van Linschoten. Met een vertaling van de Latijnse teksten bij de Icones door C.L. Heesakkers. Amsterdam: Het Spinhuis, Leiden: KITLV Uitgeverij. 
Bosboom, H.D.H.

1902

'Het verdwenen waterkasteel te Djokdjokarta (uit oude papieren)', Tijdschrift voor Indische Taal-, Land- en Volkenkunde $(T B G)$ 45:518-29.

Buettner, Elizabeth

2004 Empire families; Britons and late imperial India. Oxford: Oxford University Press.

Burke, Timothy

1996

'Sunlight soap has changed my life; Hygiene, commodification, and the body in colonial Zimbabwe', in: Hildi Hendrickson (ed.), Clothing and difference; Embodied identities in colonial and post-colonial Africa, pp. 189-212. Durham, NC: Duke University Press. [Body, Commodity, Text.]

Breet, Michael

2003 De Oost-Indische voyagie van Wouter Schouten. Zutphen: Walburg Pers.

Bijl de Vroe, C.L.M.

1980 Rondom de Buitenzorgse troon; Indisch dagboek van C.L.M. Bijl de Vroe. Ingeleid en bewerkt door Marian Schouten. Met een woord vooraf door A. Alberts. Haarlem: Fibula Van Dishoeck.

Cock Buning, W. de

1916-1917 'De Indo-Europeaan', Koloniale Studiën 1:370-402.

Cockayne, Emily

2007

Hubbub; Filth, noise E stench in England 1600-1770. New

Haven, CT/London: Yale University Press.

Collis, Maurice

1966 Raffles. London: Faber and Faber.

Corbin, Alain

1986 Pestdamp en bloesemgeur; Een geschiedenis van de reuk. Nijmegen: Sun. [Originally published as Le miasme et la jonquille;

L'odorat en l'imaginaire social, XVIII-XIX ${ }^{e}$ siècles. Paris: Aubier Montaigne, 1982.]

Crews, Robert D.

$2006 \quad$ For prophet and tsar; Islam and empire in Russia and Central Asia. Cambridge, MA/London: Harvard University Press.

Cunnington, C. Willett and Phillis Cunnington

1992

The history of underclothes. New York: Dover. [First edition 1951.] 
Curtis, L.P.

1968

Anglo-Saxons and Celts; A study of anti-Irish prejudice in Victorian England. Bridgeport, CT: Conference on British Studies at the University of Bridgeport. [Studies in British History and Culture 2.]

Dalrymple, William

2002

White Mughals; Love and betrayal in eighteenth-century India. London: HarperCollins.

2006 The last Mughal; The fall of a dynasty, Delhi, 1857. London: Bloomsbury.

Dikötter, Frank

2007

Things modern; Material culture and everyday life in China. London: Hurst.

Dumarçay, J.

'Le taman sari (Étude architecturale)', Bulletin de l'École française d'Extrême-Orient 65-2:589-625.

Dijk, Kees van

'Sarong, jubbah and trousers; Appearances as a means of distinction and discrimination', in: Henk Schulte Nordholt (ed.), Outward appearances; Dressing state and society in Indonesia, pp. 39-83. Leiden: KITLV Press. [Proceedings 4.]

Elias, Norbert

2001

Het civilisatie-proces; Sociogenetische en psychogenetische onderzoekingen. Amsterdam: Boom. [Originally published as Über den Prozess der Zivilisation; Soziogenetische und psychogenetische Untersuchungen. Basel: Haus zum Falken, 1939.]

Fisher, Michael H.

2004

Counterflows to colonialism; Indian travellers and settlers in Britain 1600-1857. Delhi: Permanent Black.

Fonvizin, Denis 2006

Brieven uit Frankrijk 1777-1778; Een Russische bojaar op grand tour aan de vooravond van de Franse Revolutie.Vertaald, ingeleid en van commentaar voorzien door Emmanuel Waegemans. Antwerpen: Benerus.

Forbes, Litton

1875 Two years in Fiji. London: Longmans, Green, and Co..

Foster, William (ed.)

1934 The voyage of Thomas Best to the East Indies. London: Hakluyt Society. [Works issued by the Hakluyt Society, Second Series, 75.] 
Fry, Michael

2001

The Scottish empire. East Lothian: Tuckwell Press, Edinburgh: Birlinn.

Garvey, Ellen Gruber

1996

The adman in the parlor; Magazines and the gendering of consumer culture, 1880s to 1910s. New York: Oxford University Press.

Gerstäcker, Fr.

1855

'Javaansche schetsen (naar het Hoogduitsch van Fr. Gerstäcker)', Bijdragen tot de Taal-, Land-en Volkenkunde 3:413-91.

Gilmour, David

2005

The ruling caste; Imperial lives in the Victorian Raj. London: Murray.

Graafland, N.

1898

De Minahassa; Haar verleden en haar tegenwoordige toestand. Tweede druk. Haarlem: Bohn. Two vols. [First edition 1867-69.]

Groneman, J.

1885

'Het waterkasteel te Jogjåkartå', Tijdschrift voor Indische Taal-, Land-en Volkenkunde (TBG) 30:412-34.

Haan, F. de

1922

Oud Batavia; Gedenkboek uitgegeven door het Bataviaasch

Genootschap van Kunsten en Wetenschappen naar aanleiding van het driehonderdjarig bestaan der stad in 1919. Batavia: Kolff. Two vols.

Halliday, Stephen

1999

The great stink of London; Sir Joseph Bazalgette and the cleansing of the Victorian metropolis. Thrupp: Sutton Publishing.

Hell, Stephan

2007

Siam and the League of Nations; Modernization, sovereignty, and multilateral diplomacy, 1920-1940. PhD thesis, University of Leiden.

Horan, Julie L.

1996

The porcelain God; A social history of the toilet. London: Robson Books.

Jasanoff, May

2005

Edge of empire; Lives, culture, and conquest in the East, 17501850. New York: Knopf.

Kabbani, Rana

1991 Europese mythen over de Oriënt. Amsterdam: Contact. 
Kildea, Paul

2006

'The proms; An industrious revolution', in: Jenny Doctor and David Wright (eds), The Proms, pp. 10-32. London: Thames \& Hudson.

King, Michelle T.

2007

'Drowning daughters'; Violence and the gendered body in nineteenth century Chinese morality books on infanticide. Paper, Fifth International Convention of Asia Scholars (ICAS5), Kuala Lumpur, 2-5 August.

Koerner, Lisber

1996

'Carl Linnaeus in his time and place', in: N. Jardine, J.A. Secord and E.C. Spary (eds), Cultures of natural history, pp. 145-62. Cambridge: Cambridge University Press.

Kopf, David 1995

'The historiography of British Orientalism, 1772-1992', in: Garland Cannon and Kevin R. Brine (eds), Objects of enquiry; The life, contributions, and influences of Sir William Jones (17461794), pp. 141-60. New York/London. New York University Press.

Kohl, Benjamin G.

1978 'Leonardo Bruni; Panegyric to the city of Florence'. Translated by Benjamin G. Kohl, in: Benjamin G. Kohl and Elizabeth B. Welles (eds), The earthy republic; Italian humanists on government and society, pp. 135-9, 149-54, 168-75. Philadelphia: University of Pennsylvania Press.

Kuus, Saskia

2007

Baden en flaneren aan zee; Badcultuur en strandmode op Scheveningen sinds 1818. Scheveningen: Muzee Scheveningen. [Historische Reeks 14.]

Lagarde, Riana

2005

'Where to pick a flower in Paris; Public restrooms'. http://www.slowtrav.com/france/paris/rl_restrooms. html.

Leeuw, Kitty de

Kleding in Nederland 1813-1920; Van een traditioneel bepaald kleedpatroon naar een begin van modern kleedgedrag. Hilversum: Verloren.

McClintock, Anne

1995

Imperial leather; Race, gender and sexuality in the colonial contest.

New York and London: Routledge. 
MacDonald, Robert H.

1994

The language of empire; Myths and metaphors of popular imperialism, 1880-1918. Manchester and New York: Manchester University Press.

Malcom, Howard

1839

Travels in South-East Asia embracing Hindustan, Malaya, Siam, and China with notices of numerous missionary stations and a full account of the Burman Empire; with dissertations, tables etc. Vol. 1. Boston: Gould, Kendall, and Lincoln.

Matthes, B.F.

'Beknopt verslag van een verblijf in de binnenlanden van Celebes, waar Boegineesch gesproken wordt, gedurende zes maanden, van 24 April tot 24 October 1856', Verzameling van Berigten betreffende de Bijbelverspreiding 91:1-28.

Maxwell, Anne

1999 Colonial photography Evexhibitions; Representations of the 'native' and the making of European identities. London and New York: Leicester University Press.

Neilly, J. Emerson

$1900 \quad$ Beseiged with B.-P; A complete record of the siege. London: Pearson. Newsome, David

The Victorian world picture; Perceptions and introspections in an age of change. London: Murray.

Oren, Michael B.

2007

Power, faith, and fantasy; America in the Middle East, 1776 to the present. New York and London: Norton.

Pakenham, Thomas

1992 The Boer War. London: Abacus.

Perrot, Philippe

1987

Werken aan de schijn; Veranderingen van het vrouwelijk lichaam in de achttiende en negentiende eeuw. Nijmegen: SUN. [Originally published as Le travail des apparences, ou les transformations du corps féminin XVIII-XIX ${ }^{e}$ siècle. Paris: Seuil, 1984.]

Platt, Kate

1923

The home and health in India and the tropical colonies. London: Baillière, Tindall and Cox.

Prabasmoro, Aquarini

2004 Becoming white; Representasi ras, kelas, feminitas dan globalitas dalam iklan sabun. Kata pengantar oleh Safrina Noorman. Bandung: Jalasustra. 
Raffles, Thomas Stamford

1978 The history of Java. Reprint. With a new introduction by John Bastin. Kuala Lumpur: Oxford University Press. Two vols. [Oxford in Asia Historical Reprints.] [First edition 1817.]

Richards, Thomas

$1990 \quad$ The commodity culture of Victorian England; Advertising and spectacle, 1851-1914. London and New York: Verso.

Roche, Daniel

2000

A history of everyday things; The birth of consumption in France, 1600-1800. Translated by Brian Pierce. Cambridge: Cambridge University Press. [Originally published as Histoire des choses banales. Paris: Fayard, 1997.]

Rouffaer, G.P and J.W. IJzerman.

1925 De eerste schipvaart der Nederlanders naar Oost-Indië onder Cornelis de Houtman 1595-1597. Journalen, documenten en andere bescheiden. Uitgegeven en toegelicht door G.P. Rouffaer en J.W. IJzerman. 's-Gravenhage: Nijhoff. [Linschoten-Vereeniging.] Schama, Simon

1988 The embarrassment of riches; An interpretation of Dutch culture in the Golden Age. N.p.: Fontana Press.

Shennan, Margaret

2000

Out in the midday sun; The British in Malaya, 1880-1960. London: Murray.

Shephard, Ben

1992 'Showbiz imperialism; The case of Peter Lobengula', in: John M. Mackenzie, Imperialism and popular culture, pp. 94-113. Manchester: Manchester University Press.

Smith, Virginia

2007

Clean; A history of personal hygiene and purity. Oxford: Oxford University Press.

Soo, May L.M. and Richard J. Stevenson

2007

'The moralisation of body odor', The Mankind Quarterly 47-3:25-56.

Spear, Percival

1998

The nabobs; A study of the social life of the English in eighteenth century India. Delhi: Oxford University Press. [Oxford India Paperbacks.]

Spence, Jonathan D.

1998

The Chan's great continent; China in Western minds. London: Penguin. 
Taylor, Jean Gelman

1983 The social world of Batavia; European and Eurasian in Dutch Asia. Madison, WI: University of Wisconsin Press.

Thorn, William

1815 Memoir of the conquest of Java; with the subsequent operations of the British forces, in the Oriental Archipelago, to which is subjoined, a statistical and historical sketch of Java; Being the result of observations made in a tour through the country; with an account of its dependencies. London: Egerton.

2004 The conquest of Java; Nineteenth century Java seen through the eyes of a soldier of the British Empire. With an introduction by John Bastin. Singapore: Periplus.

Tillotson, Sarah

1998 Indian mansions; A social history of the Haveli. New Delhi: Orient Longman.

Trautmann, Thomas R.

1997

Aryans and British India. Berkeley, CA: University of California Press.

Wall, V.I. van de

[1930] The influence of Olivia Mariamne Raffles on European society in Java (1812-1814). [Batavia]: n.n. 